\title{
Ziziphus lotus as Green Inhibitor of Copper Corrosion in Natural Sea Water
}

\author{
R. Oukhrib, ${ }^{a, *}$ El Issami, ${ }^{a}$ B. El Ibrahimi, ${ }^{a}$ K. El Mouaden, ${ }^{a}$ \\ L. Bazzi, ${ }^{a}$ L. Bammou, ${ }^{a, b}$ A. Chaouay, ${ }^{a}$ R. Salghi, ${ }^{b}$ S. Jodeh, ${ }^{c}$ \\ B. Hammouti, ${ }^{d}$ and A. Amin-Alami ${ }^{e}$
}
${ }^{a}$ Department of Chemistry, Team Applied Physical Chemistry, Laboratory of Materials and Environment, University Ibn Zohr, Faculty of Sciences, Agadir, Morocco
${ }^{b}$ Laboratory of Environmental Engineering and Biotechnology, ENSA, University Ibn Zohr, P.O. Box 1136, 80000 Agadir, Morocco
${ }^{c}$ Department of Chemistry, An-Najah National University, P.O. Box 7, Nablus, Palestine
${ }^{d}$ LCAE-URAC 18, Faculty of Sciences, University of Mohammed Premier, P.O. Box 71760000 Oujda, Morocco
${ }^{e}$ Department of Chemistry, Laboratory of Organic Chemistry, University Ibn Zohr, Faculty of Sciences, Agadir, Morocco

Received August 24, 2016; accepted February 8, 2017

\begin{abstract}
This work ultimately pays careful consideration to a method that respects the environment, and that can be developed across the accumulation of research to reduce the corrosion of metals in sea water. Extracts of Ziziphus lotus (wild jujube) were tested as a corrosion inhibitor of copper in sea water, using polarization methods and weight loss measurements. We also present by SEM the morphology of copper surface analyzed after immersion in inhibited and uninhibited electrolytes. The inhibition efficiency of Ziziphus lotus extracts was calculated and compared. We note good agreement between these methods. The obtained results revealed that the tested inhibitor significantly reduced the kinetics of the corrosion process of copper. Its efficiency increases with the concentration, and attained $93 \%$ at $5 \mathrm{~g} / \mathrm{L}$. The effect of temperature on the corrosion behavior of copper in natural sea water was also studied in the range of $293 \mathrm{~K}$ and $323 \mathrm{~K}$, to determine thermodynamic data of activation.
\end{abstract}

Keywords: Copper, corrosion inhibitor, Ziziphus lotus extracts, natural sea water.

\section{Introduction}

Because it contains corrosive elements $[1,2]$, sea water presents an important environmental and industrial problem. Indeed, the cost of corrosion, covering all

\footnotetext{
* Corresponding author. E-mail address: rachid.oukhrib1@gmail.com
} 
means of struggle, as well as the replacement of corroded parts, is considerable. To remedy this phenomenon, several methods may be adopted. Use of natural inhibitors, or of the extract of natural substances as inhibitors, is one of the most practical methods for protection against corrosion [3-7]. The reason is that plant extracts are an incredibly rich source of naturally synthesized chemical compounds that can be cheaply extracted by simple procedures, and are biodegradable in nature [3]. Therefore, Ziziphus trees are used in many traditional medicines to alleviate the effects of insomnia, skin diseases, inflammatory conditions and fever. The extract of Ziziphus lotus polyphenols modulates cell signaling and exerts immunosuppressive effects, and has been shown to possess anti-inflammatory and analgesic properties; the seed extracts exert the most potent immunosuppressive effects on $\mathrm{T}$ cell proliferation. This extract has also a gastro-protective benefit, which may be due to its anti-acid effect; it contains anti-spasmodic constituents mediating their effect through cholinergic receptors and blocking $\mathrm{Ca}^{2+}$ influx. In addition to the many researches in the medical field [8-14] that recognize and support the importance of plants' components in health, there have been researches for novel compounds as inhibitors of metal corrosion extracted from natural and no toxic substances $[4,15]$. These include testing at the protection of copper against the phenomenon of corrosion in natural sea water [16-19]. Recent work by our research team involves testing the corrosion inhibition of copper by natural sea water on the beach of Agadir, by using some natural extracts from plants such as Wild jujube Ziziphus lotus (L.) Lam. We have tested the inhibitory potency based on several parameters: effect of concentration, temperature and immersion time. For the realization of this work we have used stationary and transient electrochemical methods coupled with the gravimetric method. The obtained results show that the effectiveness of inhibition increases with the inhibitor's concentration. The goal of this study is to find an environmentally safe and inexpensive inhibitor (Ziziphus lotus extract), and evaluate its efficiency against the corrosion of copper in natural sea water.

\section{Materials and methods \\ Sea water samples}

Area of the samples

The sampling area is located on Agadir beach, about $2 \mathrm{~km}$ south of the port, as shown in Fig. 1, between $\mathrm{P} 1(\mathrm{X}=96218,632$; $\mathrm{Y}=385938,244)$ and $\mathrm{P} 2(\mathrm{X}=96313$, $633 ; \mathrm{Y}=385381,447)$.

\section{Physicochemical parameters}

We have periodically collected large quantities of sea water from the specified area, every time measuring the following factors (physicochemical parameters): dissolved oxygen, $\mathrm{pH}$, salinity, conductivity and temperature. Table 1 shows the found average values. 


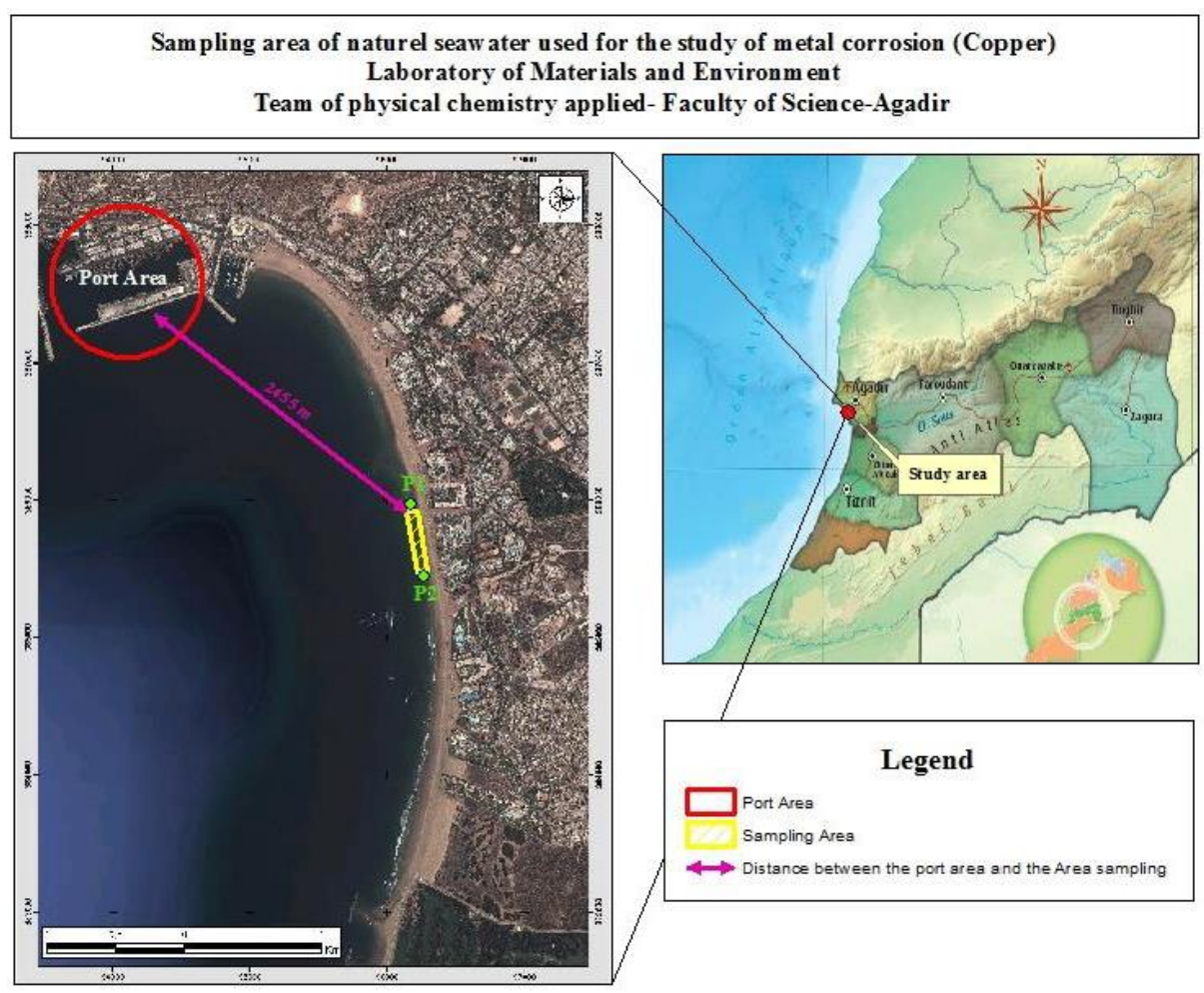

Figure 1. Sampling site of sea water.

Table 1. Physicochemical parameters of sample sea water.

\begin{tabular}{lc}
\hline Physicochemical parameters & Average value \\
\hline Dissolved oxygen $(\mathbf{m g} / \mathbf{L})$ & 6.8 \\
pH & 8.21 \\
Salinity $(\mathbf{m g} / \mathbf{L})$ & 36500 \\
Conductivity $(\boldsymbol{\mu s} / \mathbf{c m})$ & 54800 \\
T $\left({ }^{\circ} \mathbf{C}\right)$ & 19 \\
\hline
\end{tabular}

\section{Botanic and chemical composition of Ziziphus lotus}

Ziziphus lotus (L.) is a perennial deciduous shrub of the Rhamnaceae buckthorn family, native to the Mediterranean region, including Palestine, Morocco, Algeria, Tunisia and Libya. Ziziphus lotus can reach a height of 2.5 meters, with shiny and bright green leaves about $5 \mathrm{~cm}$ long. The edible fruit is a globose dark yellow drupe, about 1-1.5 cm diameter, called nabk. Common names in Arabic are sedra, rubeida ("after its crouch-shaped treetop"), nbeg in Tunisia, zizaphon in Palestine and annab in Lebanon [20-23]. Ziziphus lotus is classified in the division Magnoliophyta, class Magnoliopsida, order Rhamnales, and it belongs to the Rhamnaceae family, Ziziphus genus [22,24].

Ziziphus lotus is a fruit pulp which contains linoleic acid, vitamin $\mathrm{A}$ and $\mathrm{C}$ $[24,25]$, as well as vitamin E [24-27]. Through the analysis of the sample by infrared Spectroscopy Fourier Transform, which is presented in Fig. 2, we have tried to identify the most important functions of this plant's molecules.

\section{Sample preparation}

The pulp of Ziziphus lotus was collected in the region of Agadir, in Morocco (in the summer of 2013), and the voucher specimen code is Pharm-PCT-2691. 
Powder plant was air-dried in the laboratory at room temperature. A sample of 6 $\mathrm{g}$ was subjected to collected sea water, and the solution was mixed for 24 hours at room temperature. After the filtration of the mixture, anther media were prepared by dilution in distilled water. It should be noted that each sample was immediately prepared before each experiment.

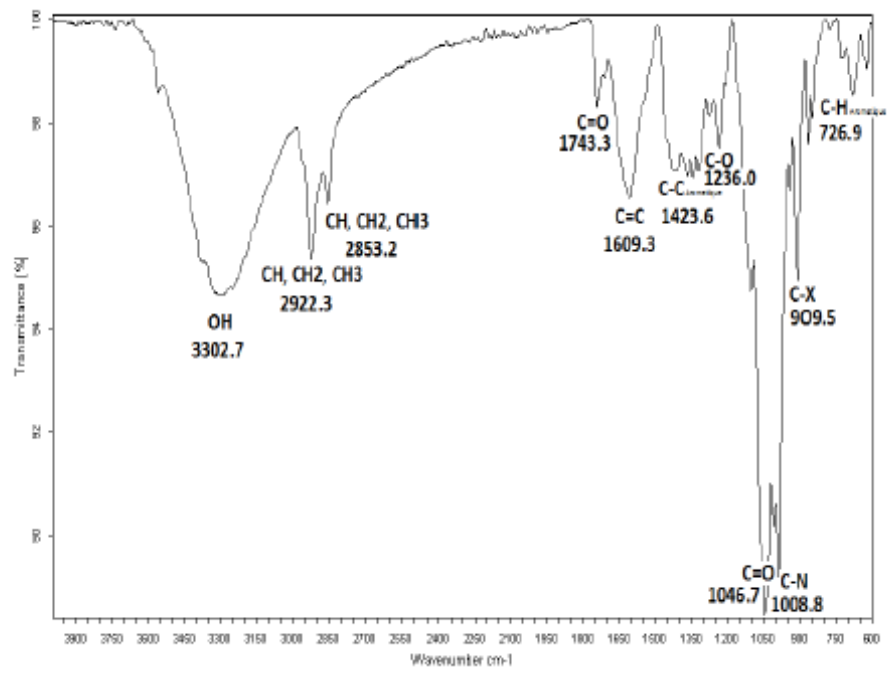

Figure 2. FTIR spectrum of Ziziphus lotus.

In Fig. 3 we represent Linoleic acid, Vitamin A, C and E molecules, and then link the bands of the IR spectrum to the functional groups of these molecules.

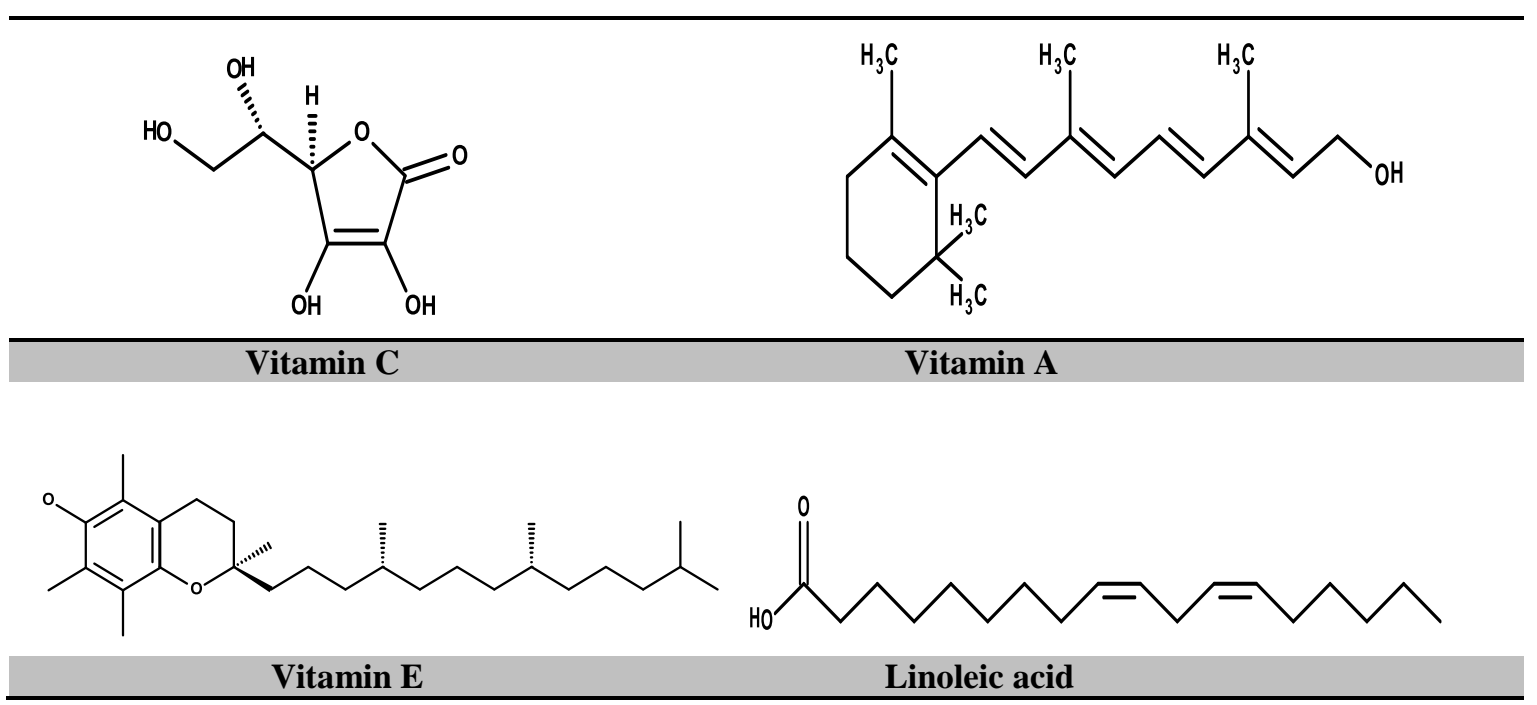

Figure 3. Majority of molecules in Ziziphus lotus extract.

\section{Measurements}

\section{Electrochemical tests}

The electrochemical measurements were carried out using a potentiostat PGZ301 piloted by Volta Master 4 software. The potentiostat is connected to a thermostatically controlled cell with double wall and three electrodes. The copper 
working electrode (WE) in the cylindrical form has a disc with $0.8 \mathrm{~cm}^{2}$, and is embedded in a tube of polytetrafluoroethylene (PTFE), fixed by araldite, which is a glue made from an epoxy resin, and a polymerizing agent. A saturated calomel electrode (SCE) and a wire of platinum electrode $(\mathrm{Pt})$ were, respectively, used as reference and auxiliary electrodes. The temperature was thermostatically controlled at $293 \pm 1 \mathrm{~K}$. The WE was abraded with silicon carbide paper (grade P1200) under a stream of water, and rinsed with distilled water, degreased before use.

\section{Weight loss measurements}

The samples of natural sea water (aggressive) were brought in sufficient quantities, from the exact location. Prior to all measurements, the used copper samples were $99 \%$ pure, polished with different emery papers up to 1200 grade, thoroughly washed with distilled water, degreased with acetone and dried at room temperature.

Gravimetric measurements were performed in a plastic cell dedicated for this purpose. The solution volume was $80 \mathrm{~mL}$. The used copper specimens had a rectangular form $(2 \mathrm{~cm} \times 2 \mathrm{~cm} \times 0.05 \mathrm{~cm})$. The immersion times for the weight loss were $8 \mathrm{hrs}, 24 \mathrm{hrs}, 48 \mathrm{hrs}, 72 \mathrm{hrs}, 100 \mathrm{hrs}$, and $168 \mathrm{hrs}$, at room temperature. After the corrosion test, the copper specimens were carefully washed in distilled water, dried and then weighed. The removed rinse lost segments of the film of the corroded samples. Experiments were performed three times in each case (to ensure profitability results), and the mean value of the weight loss was reported. Weight loss allowed us to calculate the mean corrosion rate as expressed in mg. $\mathrm{cm}^{-2} \mathrm{~h}^{-1}$.

We have also studied the effect of temperature on the corrosion rate of copper in natural sea water, with a concentration of $5 \mathrm{~g} / \mathrm{L}$ of inhibitor. The study was carried out in the temperature range of 293-323 K.

\section{Scanning electron microscopy (SEM)}

Rectangular copper pieces were prepared by their immersion in natural sea water, with and without the optimal concentration of inhibitor, and analysis surface was performed using SEM environmental type (FEI ESEM Quanta 200 Environmental Scanning Electron Microscope), to analyze the surface morphology.

\section{Results and discussion}

\section{Electrochemical tests}

\section{Polarization measurements}

Polarization measurements have been carried out in order to gain knowledge on the kinetics of anodic and cathodic reactions. Current-potential characteristics resulting from cathodic and anodic polarization curves of copper (working electrode), at various concentrations of Ziziphus lotus extract in natural sea water, were evaluated. The corrosion inhibition efficiency $(\%)$ was calculated by the equation (1): 


$$
\mathrm{EI}=\left(\left(\mathrm{I}_{\mathrm{Corr}}-\mathrm{I}_{\mathrm{Corr}(\mathrm{inh})}\right) / \mathrm{I}_{\mathrm{Corr}}\right) \times 100
$$

The cathodic and anodic polarization curves of copper in natural sea water, in the absence and presence of Ziziphus lotus extract at different concentrations at 298 $\mathrm{K}$, are presented in Fig. 4. The distinct break that can be identified at anodic curve regions, almost for the potential of $+80 \mathrm{mV} / \mathrm{SCE}$, is explicable by the anodic dissolution of copper. The anodic dissolution of copper in sea water is reported in many studies[28-30]; this is due to the formation of $\mathrm{CuCl}$, which explains the presence of a region of decreasing currents until a minimum, and a region of increase in current density .

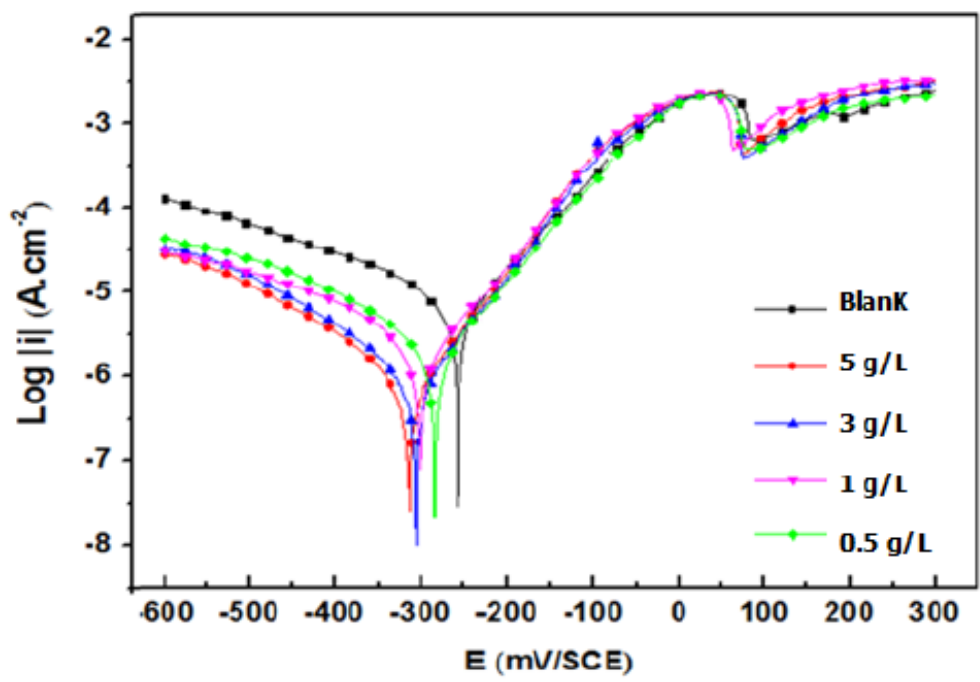

Figure 4. Cathodic and anodic polarization curves of copper obtained in natural sea water at various concentrations of Ziziphus lotus extract.

The corrosion kinetic parameters, such as $\mathrm{E}_{\mathrm{Corr}}, \mathrm{I}_{\mathrm{Corr}}$, and $\beta \mathrm{a}$, obtained from potentiodynamic polarization curves for copper in natural sea water containing different concentrations of Ziziphus lotus extract, are summarized in Table 2.

Table 2. Electrochemical parameters of copper at various concentrations of Ziziphus lotus extract in natural sea water, and corresponding inhibition efficiency.

\begin{tabular}{ccccc}
\hline $\begin{array}{c}\text { Ziziphus lotus } \\
\text { extract (g/L) }\end{array}$ & $\begin{array}{c}\text {-ECorr } \\
(\mathbf{m V / S C E})\end{array}$ & $\begin{array}{c}\mathbf{I} \text { Corr } \\
\left(\boldsymbol{\mu} \mathbf{A} / \mathbf{c m}^{2}\right)\end{array}$ & $\begin{array}{c}\boldsymbol{\beta a} \\
(\mathbf{m V / d e c})\end{array}$ & $\mathbf{E}_{\mathbf{I}}(\boldsymbol{\%})$ \\
\hline BlanK & 291 & 6.06 & 76 & ----- \\
$\mathbf{0 . 5}$ & 383 & 1.35 & 70 & 77 \\
$\mathbf{1}$ & 301 & 1.00 & 67 & 83 \\
$\mathbf{3}$ & 303 & 0.50 & 67 & 91 \\
$\mathbf{5}$ & 312 & 0.40 & 62 & 93 \\
\hline
\end{tabular}

The data displayed in the table above show that increasing the inhibitor concentration decreases the $\mathrm{I}_{\text {corr }}$, reaching $0.4 \mu \mathrm{A} / \mathrm{cm}^{2}$ at $5 \mathrm{~g} / \mathrm{L}$ of Ziziphus lotus extract. This explains the change in the effectiveness of an inhibitor which reaches $93 \%$, but the values of ECorr remain approximately close to each other. The values of $\beta$ a are slightly changed because the curves are nearly identical in the anodic part. 


\section{Temperature effect}

The effect of temperature on the corrosion behavior of copper in sea water, containing the inhibitor at a concentration of $5 \mathrm{~g} / \mathrm{L}$, is studied in the temperature range of 293-323 K, using electrochemical measurements.

The obtained anodic and cathodic polarization curves are shown in Fig. 5.

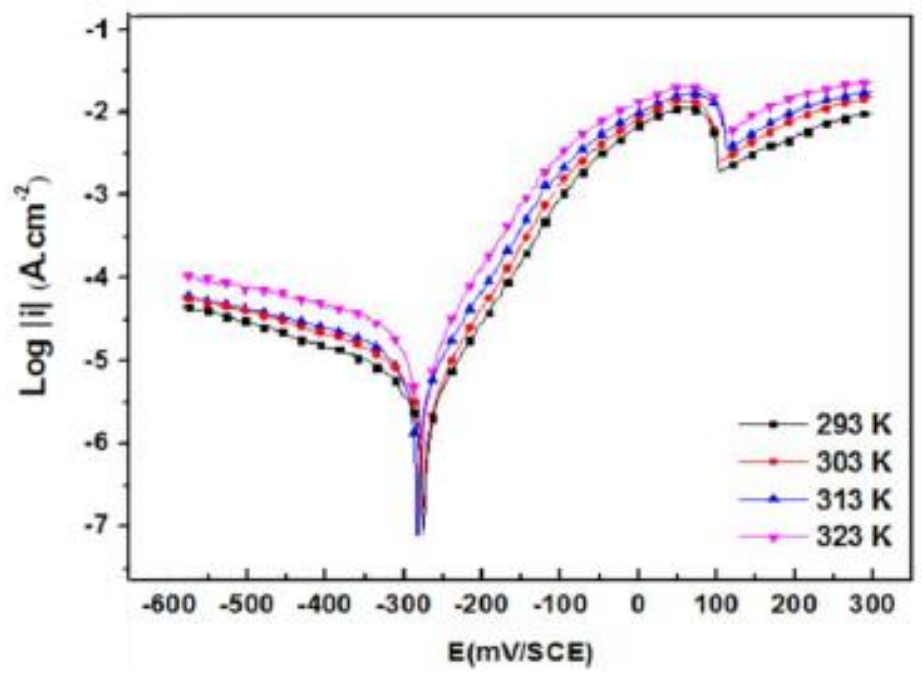

Figure 5. Potentiodynamic polarization curves of copper in natural sea water with $5 \mathrm{~g} / \mathrm{L}$ of Ziziphus lotus extract at different temperatures.

The corresponding electrochemical parameters deduced from these curves, especially the current density, $\mathrm{I}_{\mathrm{Corr}}$, depending on the temperature, show that the corrosion phenomenon is equally related to temperature. The parameters are regrouped in Table 3.

Table 3. Polarization parameters of copper in natural sea water whit $5 \mathrm{~g} / \mathrm{L}$ of Ziziphus lotus extract at different temperatures.

\begin{tabular}{|c|c|c|c|c|c|}
\hline $\begin{array}{c}\text { Concentration } \\
(\mathrm{g} / \mathrm{L})\end{array}$ & $\begin{array}{c}\text { Temperature } \\
\text { (K) }\end{array}$ & $\begin{array}{c}\text {-ECorr } \\
(\mathrm{mV} / \mathrm{SCE})\end{array}$ & $\begin{array}{c}\mathbf{\beta a} \\
\left(\mathbf{m V} \text { dec }^{-1}\right)\end{array}$ & $\begin{array}{c}I_{\text {Corr }} \\
\left(\mu \mathbf{A ~ c m}^{-2}\right)\end{array}$ & $\begin{array}{l}\mathrm{E}_{I} \\
(\%)\end{array}$ \\
\hline \multirow{4}{*}{ Blank } & 293 & 291 & 76 & 6.06 & ---- \\
\hline & 303 & 312 & 72 & 6.50 & ---- \\
\hline & 313 & 306 & 63 & 6.74 & ---- \\
\hline & 323 & 314 & 74 & 7.55 & ---- \\
\hline \multirow{4}{*}{$5 \mathrm{~g} / \mathrm{L}$} & 293 & 312 & 62 & 0.40 & 93 \\
\hline & 303 & 275 & 63 & 2.60 & 60 \\
\hline & 313 & 284 & 67 & 3.68 & 45 \\
\hline & 323 & 279 & 66 & 4.90 & 35 \\
\hline
\end{tabular}

From the results in the table above we seek to show that increasing the temperature increases the Icorr, reaching $7.55 \mu \mathrm{A} / \mathrm{cm}^{2}$ in absence of the inhibitor, and reaching $4.90 \mu \mathrm{A} / \mathrm{cm}^{2}$ in the presence of $5 \mathrm{~g} / \mathrm{L}$ of Ziziphus lotus extract at $323 \mathrm{~K}$; the other electrochemical parameters $\mathrm{E}_{\mathrm{Corr}}$ and $\beta \mathrm{a}$ are slightly changed.

The anodic and cathodic polarization curves of copper in the corrosive medium at different temperatures in the range of 293-323 K are shown in Fig. 6. 


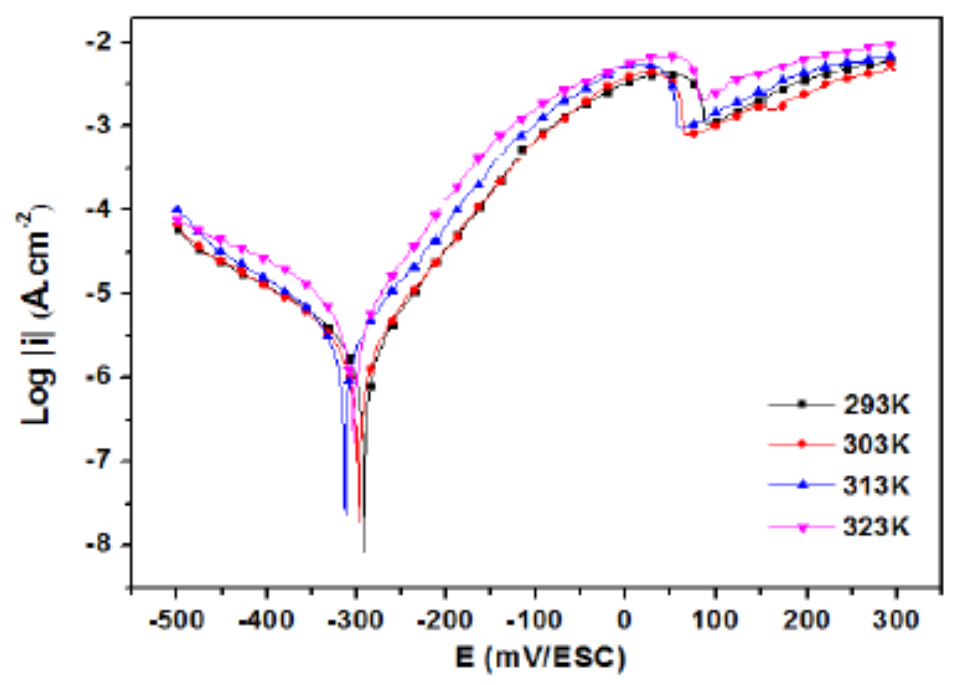

Figure 6. Potentiodynamic polarization curves of copper in natural sea water.

\section{Gravimetric measurements}

\section{Concentration effect}

The corrosion rate, $\mathrm{W}_{\text {Corr, }}$ and efficiency inhibition, $\mathrm{E}_{\mathrm{W}} \%$, of copper corrosion in different solutions (sea water + different Ziziphus lotus extracts in 0.5, 1, 3 and 5 $\mathrm{g} / \mathrm{L})$ were determined after testing the immersion time $(8 \mathrm{hrs}, 24 \mathrm{hrs}, 48 \mathrm{hrs}, 72$ $\mathrm{hrs}, 100 \mathrm{hrs}$, and $168 \mathrm{hrs}$ ) at $298 \pm 1 \mathrm{~K}$. The corrosion rate and the efficiency inhibition values are respectively given in Tables 4 and 5 .

Table 4. The corrosion rate of copper in natural sea water, with addition of Ziziphus lotus extract at various immersion times $(\mathrm{T}=298 \pm 1 \mathrm{~K})$.

\begin{tabular}{c|ccccc}
\hline \multirow{2}{*}{ Concentration(g/L) } & \multicolumn{5}{|c}{$W_{\text {Corr }}\left(\mathbf{m g} / \mathbf{h . c m} \mathbf{c m}^{\mathbf{2}} \mathbf{\mathbf { 1 0 } ^ { - 3 }}\right.$} \\
\cline { 2 - 6 } & $\mathbf{8} \mathbf{~ h r s}$ & $\mathbf{2 4} \mathbf{~ h r s}$ & $\mathbf{7 2} \mathbf{~ h r s}$ & $\mathbf{9 6} \mathbf{~ h r s}$ & $\mathbf{1 6 8} \mathbf{~ h r s}$ \\
\hline $\mathbf{0}$ & 39.4 & 16.5 & 13.2 & 11.7 & 10.5 \\
$\mathbf{0} .5$ & 18.5 & 11.0 & 9.50 & 9.00 & 8.60 \\
$\mathbf{1}$ & 9.40 & 8.90 & 7.30 & 7.00 & 6.20 \\
$\mathbf{3}$ & 5.70 & 5.30 & 5.00 & 4.40 & 4.00 \\
$\mathbf{5}$ & 4.20 & 2.90 & 2.30 & 2.00 & 1.70 \\
\hline
\end{tabular}

Table 5. Inhibition efficiency, depending on the concentrations of Ziziphus lotus extract in natural sea water.

\begin{tabular}{c|ccccc}
\hline \multirow{2}{*}{ Concentration (g/L) } & \multicolumn{5}{|c}{ Inhibition efficiency, Ew (\%) } \\
\cline { 2 - 6 } & $\mathbf{8}$ hrs & $\mathbf{2 4}$ hrs & $\mathbf{7 2}$ hrs & $\mathbf{9 6}$ hrs & $\mathbf{1 6 8}$ hrs \\
\hline $\mathbf{0 . 5}$ & 53 & 33 & 28 & 23 & 18 \\
$\mathbf{1}$ & 76 & 46 & 44 & 40 & 40 \\
$\mathbf{3}$ & 85 & 68 & 62 & 62 & 52 \\
$\mathbf{5}$ & 89 & 82 & 82 & 83 & 84 \\
\hline
\end{tabular}

In the case of weight loss method, the corrosion rate, $\mathrm{W}_{\text {Corr, }}$ was determined by the following relationship (2):

$$
\mathrm{W}_{\mathrm{Corr}}=\left(\mathrm{m}-\mathrm{m}_{0)}\right) / \Delta \mathrm{T} \times \mathrm{S}
$$


where: $\mathrm{m}-\mathrm{m}_{0}$ is the weight-loss in milligrams, $\Delta \mathrm{T}$ is the time of exposure of the metal sample in hours and $\mathrm{S}$ is the area of sample in $\mathrm{cm}^{2}$.

The interpretation of summarized results in Fig. 7 and Table 4 shows clearly that the corrosion rate $\mathrm{W}_{\text {Corr }}\left(\mathrm{mg} / \mathrm{h} . \mathrm{cm}^{2}\right)$ decreases, while Fig. 8 and Table 5 show that the inhibition efficiency, $\mathrm{E}_{\mathrm{W}}(\%)$, increases with increased inhibitor concentration, reaching a maximum value of $89 \%$ at a concentration of $5 \mathrm{~g} / \mathrm{L}$ with $8 \mathrm{hrs}$ of exposure time.

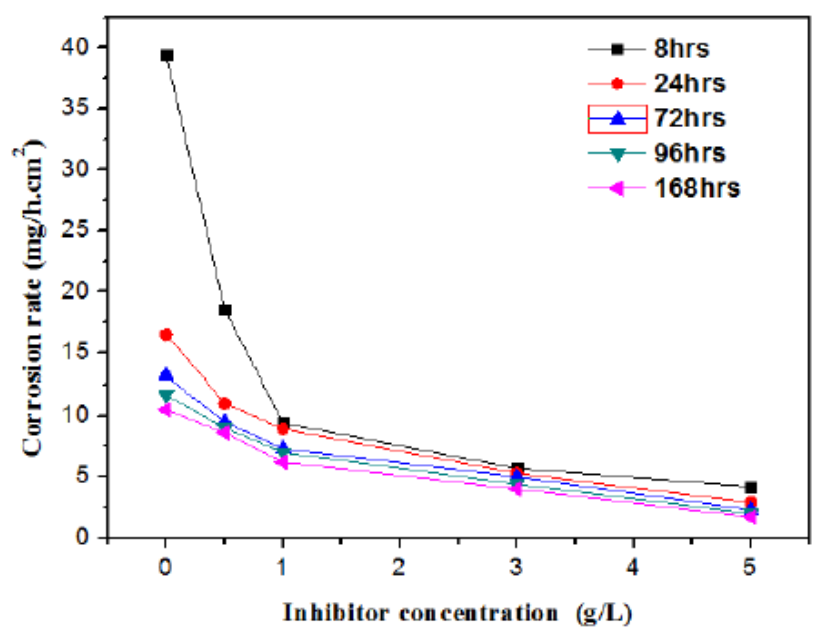

Figure 7. Variation of copper corrosion rate, depending on the concentration of Ziziphus lotus extract in natural sea water.

And the efficiency of inhibition, $\mathrm{E}_{\mathrm{W}} \%$, was determined by the following relationship (3):

$$
\mathrm{E}_{\mathrm{W}} \%=\left(1-\left(\mathrm{W}_{\text {Corr(inhib) }} / \mathrm{W}_{\text {Corr }}\right)\right) \times 100
$$

where $\mathrm{W}_{\text {Corr }}$ is the corrosion rate of the sample in the blank solution and $\mathrm{W}_{\text {Corr (inh) }}$ is the corrosion rate of the sample in presence of the inhibitor additive.

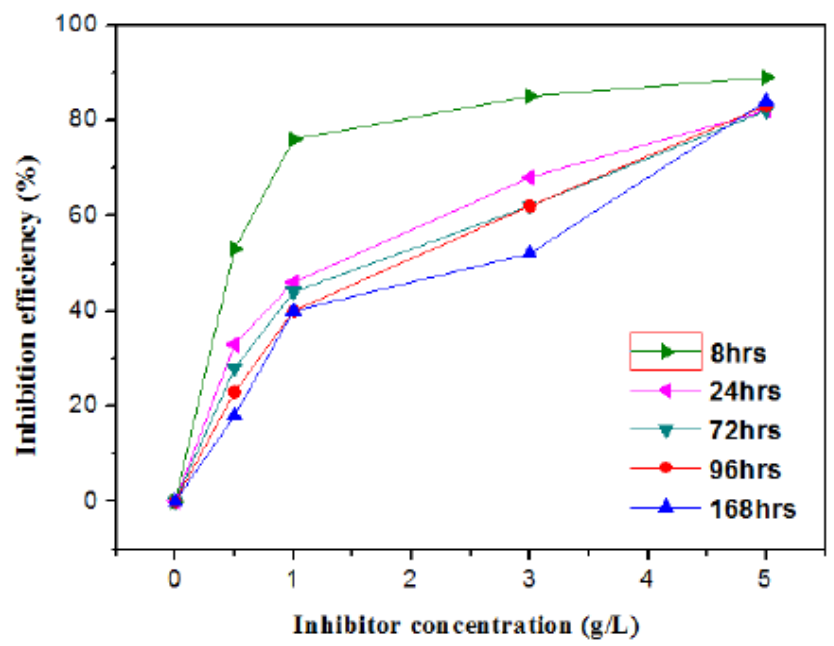

Figure 8. Variation of inhibition efficiency, depending on the concentrations of Ziziphus lotus extract in natural sea water. 
To follow the progress of copper corrosion rate, $\mathrm{W}_{\text {corr, }}$ depending on the efficiency of inhibition in various solutions (sea water + various contents of Ziziphus lotus extracts), the values of corrosion rate and efficiency of inhibition, determined after the immersion time $\mathrm{t}=8 \mathrm{hrs}$ at $298 \pm 1 \mathrm{~K}$, are given in Fig. 9 and Table 6.

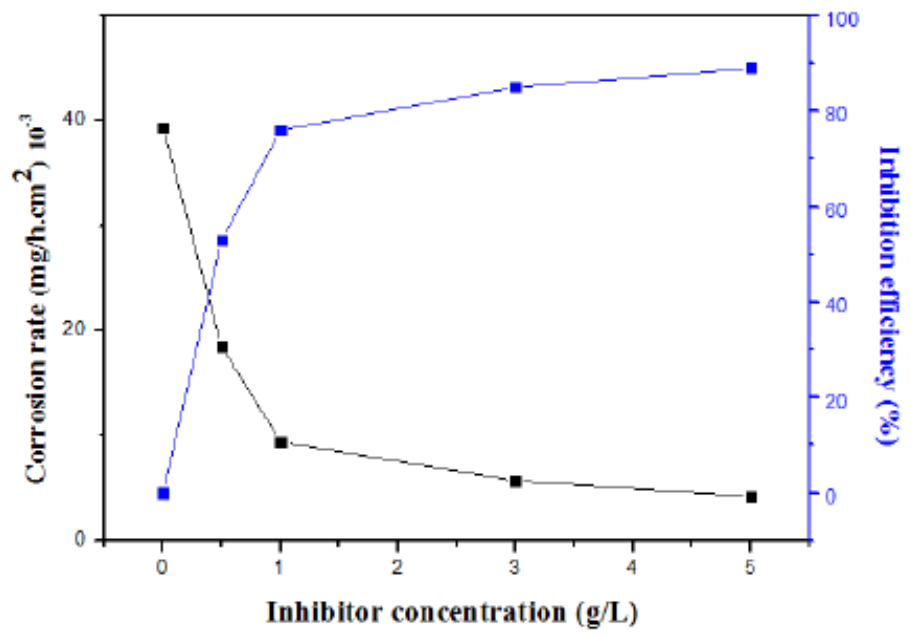

Figure 9. Variation of corrosion rate and inhibition efficiency of copper in natural sea water (without and with Ziziphus lotus extract at the immersion time $\mathrm{t}=8 \mathrm{hrs}$ and $\mathrm{T}=$ $298 \pm 1 \mathrm{~K})$.

Table 6. Gravimetric results of copper in natural sea water, without and with addition of the Ziziphus lotus extract at the immersion time $\mathrm{t}=8 \mathrm{hrs}$ and $\mathrm{T}=298 \pm 1 \mathrm{~K}$.

\begin{tabular}{ccc}
\hline Concentrations (g/L) & $\mathbf{W}_{\text {Corr }}\left(\mathbf{m g} / \mathbf{h h . c m}^{\mathbf{2}}\right) \mathbf{1 0}^{-\mathbf{3}}$ & $\mathbf{E}_{\mathbf{W}}(\boldsymbol{\%})$ \\
\hline BlanK & 39.4 & 0 \\
$\mathbf{0 . 5}$ & 18.5 & 53 \\
$\mathbf{1}$ & 9.40 & 76 \\
$\mathbf{3}$ & 5.70 & 85 \\
$\mathbf{5}$ & 4.20 & 89 \\
\hline
\end{tabular}

The analysis of these results clearly shows that the corrosion rate, $\mathrm{W}_{\text {Corr }}$ $\left(\mathrm{mg} / \mathrm{h} . \mathrm{cm}^{2}\right)$, decreases, while the inhibition efficiency, $\mathrm{E}_{\mathrm{W}} \%$, increases, with an increasing concentration of the inhibitor, reaching a maximum value of $89 \%$ at a concentration of $5 \mathrm{~g} / \mathrm{L}$.

\section{Temperature effect}

The temperature effect, for one hour, on the corrosion behavior of copper in natural sea water with a concentration of $5 \mathrm{~g} / \mathrm{L}$ of inhibitor, is studied in the temperature range of 293-323 K, using weight loss measurements. Table 7 regroups the obtained corresponding results.

Table 7. Effects of temperature on the copper corrosion in natural sea water in the presence and absence of $5 \mathrm{~g} / \mathrm{L}$ of inhibitor for 1 hour of immersion.

\begin{tabular}{cccc}
\hline Temperature (K) & $\mathbf{W}^{\mathbf{\prime}}\left(\mathbf{m g} / \mathbf{c m}^{\mathbf{2}} \mathbf{. h}\right) \mathbf{1 0}^{-\mathbf{3}}$ & $\mathbf{W}\left(\mathbf{m g} / \mathbf{c m}^{\mathbf{2}} \mathbf{. h}\right) \mathbf{1 0}^{-\mathbf{3}}$ & $\mathbf{E}_{\mathbf{W}} \mathbf{( \% )}$ \\
\hline $\mathbf{2 9 3}$ & 0.125 & 0.050 & 60 \\
$\mathbf{3 0 3}$ & 0.190 & 0.100 & 47 \\
$\mathbf{3 1 3}$ & 0.275 & 0.150 & 45 \\
$\mathbf{3 2 3}$ & 0.375 & 0.275 & 27 \\
\hline
\end{tabular}


From the experimental data we note that the corrosion rate increases both in the uninhibited and inhibited sea water, with the rise of temperature [31-36]. In the case of presence of the inhibitor the corrosion rate is reduced. The following relations (4) can determine the apparent activation energy:

$$
\mathrm{W}_{\mathrm{Corr}}=\mathrm{K} \exp \left(-\mathrm{E}_{\mathrm{a}} / \mathrm{RT}\right) \quad \text { and } \quad \mathrm{W}^{\prime}{ }_{\mathrm{Corr}}=\mathrm{K}^{\prime} \exp \left(-\mathrm{E}_{\mathrm{a}}{ }_{\mathrm{a}} / \mathrm{RT}\right)
$$

$\mathrm{W}^{\prime}$ Corr and $\mathrm{W}_{\text {Corr }}\left(\mathrm{mg} / \mathrm{h} . \mathrm{cm}^{2}\right)$ are the corrosion rates of copper, respectively without and with the inhibitor, determined by the weight-loss method. $\mathrm{E}_{\mathrm{a}}$ and $\mathrm{E}_{\mathrm{a}}$ $(\mathrm{Kj} / \mathrm{mol})$ are the apparent activation energies, respectively, in the presence and absence of inhibitor, and $\mathrm{T}$ is the absolute temperature $(\mathrm{K})$.

Arrhenius plots for the corrosion rates of copper are shown in Fig. 10. The calculated values of activation energies from the slopes show that the activation energy increases with the increased concentration of inhibitor [37-40]. The obtained results are $28.86 \mathrm{~kJ} / \mathrm{mol}$ for the blank (sea water without inhibitor), and $43.42 \mathrm{~kJ} / \mathrm{mol}$ for sea water with addition of $5 \mathrm{~g} / \mathrm{L}$ of Ziziphus lotus extracts. The change on the values of the apparent activation energies may be explained by the modification of the mechanism of the corrosion process in the presence of adsorbed inhibitor molecules $[41,42]$.

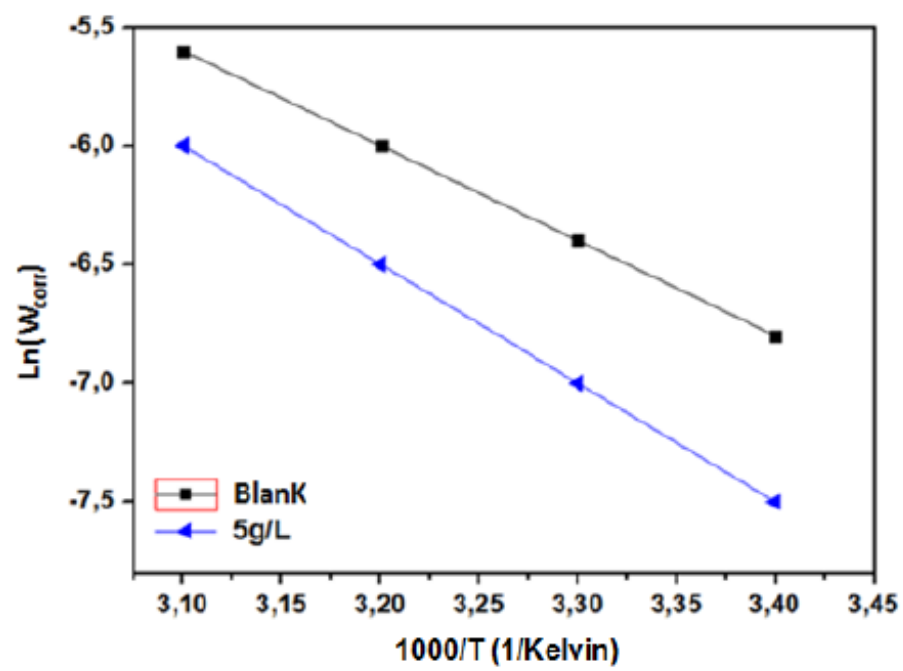

Figure 10. Arrhenius plots of copper in uninhibited and inhibited natural sea water.

The efficiency of the inhibitor "Ziziphus lotus" can be explained by the inhibition process of its constituent molecules. The Fourier transform infrared (FTIR) spectrum of the analyzed sample shows that Ziziphus lotus is composed of a mixture of several molecules (Fig. 2) These functional groups and the heteroatoms, such as oxygen $(\mathrm{O})$, which is available in particular in vitamins $\mathrm{C}, \mathrm{A}, \mathrm{E}$, and Linoleic acid, may exchange electrons with the metal, and may increase the polarity and the adsorbability of the inhibitor on the surface of copper. This can be interpreted as an augmentation of the l'IE, with an increase in the portion of the metal surface coated in accordance with the increase in the concentration of the inhibitor $[43,44]$. Thus, the inhibiting effect of the Ziziphus lotus extract may 
be essentially attributed to these functions, and the active sites of the major components that can adsorb on the metal surface block the active sites on the surface, thereby reducing the corrosion rate [45-49]. The analysis of the FTIR spectrum of Ziziphus lotus, and of its possible characteristic bands, is summarized in Table 8:

Table 8. Characteristic bands in the FTIR spectrum of Ziziphus lotus.

\begin{tabular}{|c|c|c|c|c|c|}
\hline Bands & $\mathrm{Cm}^{-1}$ & Characteristic bands & Bands & $\mathrm{Cm}^{-1}$ & Characteristic bands \\
\hline 1 & $\begin{array}{l}\mathbf{3 3 0 2 . 7} \\
\approx 3300\end{array}$ & $\begin{array}{c}\text { Characterize the }[\mathbf{O H}]==> \\
\text { possible especially as the band } \\
\text { is wide }\end{array}$ & 7 & $\begin{array}{l}\mathbf{1 2 3 6 . 0} \\
\approx 1200\end{array}$ & $\begin{array}{l}\text { Characterize the band }[\mathbf{C - O}] \\
==>\text { possible }\end{array}$ \\
\hline 2 & $\begin{array}{l}\mathbf{2 9 2 2 . 3} \\
\approx 2900\end{array}$ & $\begin{array}{c}\text { Characterize the band } \mathbf{C H} \text {, } \\
\text { CH2 or } \mathbf{C H 3}\end{array}$ & 8 & $\begin{array}{l}\mathbf{1 0 4 6 . 7} \\
\approx 1050\end{array}$ & Characterize the band $[\mathbf{C}=\mathbf{O}]$ \\
\hline 3 & $\begin{array}{l}\mathbf{2 8 5 3 . 2} \\
\approx 2850\end{array}$ & $\begin{array}{c}\text { Characterize the band } \mathbf{C H}, \\
\mathbf{C H 2} \text { or } \mathbf{C H 3}\end{array}$ & 9 & $\begin{array}{l}\mathbf{1 0 0 8 . 8} \\
\approx 1000\end{array}$ & $\begin{array}{l}\text { Characterize the band }[\mathbf{C}-\mathbf{N}] \\
\text { possible }\end{array}$ \\
\hline 4 & $\begin{array}{l}\mathbf{1 7 4 3 . 3} \\
\approx 1750\end{array}$ & $\begin{array}{c}\text { Characterize the }[\mathbf{C}=\mathbf{O}]==> \\
\text { possible }\end{array}$ & 10 & $\begin{array}{l}\mathbf{9 0 9 . 5} \\
\approx 900\end{array}$ & $\begin{array}{l}\text { Characterize the band [C-X] } \\
==>\text { because, between } \mathbf{1 0 0 0} \\
\text { and } \mathbf{5 0 0 c m - 1} \text { are found } \mathbf{C H} \\
\text { deformation band of an alkene } \\
\text { or of an aromatic }\end{array}$ \\
\hline 5 & $\begin{array}{l}\mathbf{1 6 0 9 . 3} \\
\approx 1600\end{array}$ & $\begin{array}{c}\text { Characterize the band }[\mathbf{C}=\mathbf{C}] \\
==>\text { possible }\end{array}$ & 11 & $\begin{array}{l}\mathbf{7 2 6 . 9} \\
\approx 700\end{array}$ & $\begin{array}{c}\text { Aromatic band }[\mathbf{C}-\mathbf{H}]==> \\
\text { possible }\end{array}$ \\
\hline 6 & $\begin{array}{l}\mathbf{1 4 2 3 . 6} \\
\approx 1400\end{array}$ & Aromatic band [C-C] & & & \\
\hline
\end{tabular}

\section{SEM Analysis}

The photomicrographs of the copper surface obtained by scanning electron microscope (SEM), after their immersion in natural sea water with and without the addition of the inhibitor at room temperature, allowed characterization of the inhibitor action on the metal surface.
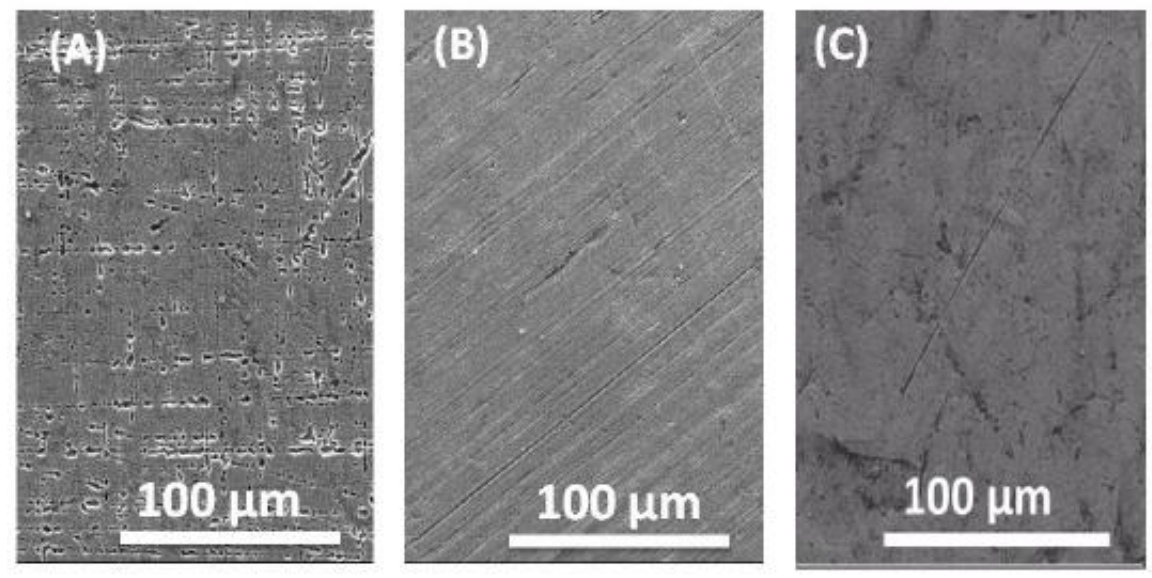

Figure 11. SEM (x1000) of pure copper: (A) after 24 hours of immersion in natural sea water without inhibitor, (B) after 24 hours of immersion in natural sea water with inhibitor, and $(\mathrm{C})$ the untreated surface.

After 24 hours of immersion and through observation, Fig. 11 shows that the specimen surface (A) of copper analyzed after immersion in natural sea water without inhibitor appears widely jagged, and the porous layer of corrosion 
product is present. In contrast, the image (B), which shows the state of the surface after its immersion in sea water with inhibitor, was a smooth surface with deposited extract. Lastly, the untreated surface (C) used as reference showed a decline of the state of corrosion on account of the thick films which formed on the copper surface. This may be intercepted by the adsorption of the inhibitor onto the copper surface [50-53].

\section{Conclusion}

In this study, the Ziziphus lotus extract was investigated as a corrosion inhibitor for copper in natural sea water medium, by weight loss measurements, electrochemical tests and SEM examination. The results show that the main components of Ziziphus lotus extract, which are linoleic acid, vitamin A and $\mathrm{C}$, as well as vitamin E, inhibit the corrosion of copper in natural sea water, and the inhibition efficiency increases with an increased concentration of the inhibitor; by the same token, the activation energy increases with an increased inhibitor's concentration. The addition of inhibitor was found to affect the cathodic process, and the inhibition efficiency of Ziziphus lotus extract increases with an increased concentration, to attain $93 \%$ at $5 \mathrm{~g} / \mathrm{L}$. The inhibition efficiency of Ziziphus lotus extracts, which may be explained on the basis of adsorption of their main components onto the copper surface, decreases with the rise of temperature. Mostly, the results obtained from different methods, whether potentiodynamic polarization or weight loss, are in good agreement. SEM examination of the electrode surface confirmed that the decline of the state of corrosion is due to the formation of chemisorbed films, which formed on the copper surface.

\section{References}

1. Millero FJ, Feistel R, Wright DG, et al. Deep Sea Res Part I Oceanogr Res Pap. 2008;50:72.

2. Butler BM, Papadimitriou S, Kennedy H. Marine Chem. 2016;21:31.

3. Satapathy AK, Gunasekaran G, Sahoo SC, et al. Corros Sci. 2009;2848:56.

4. Antonijevic MM, Petrovic MB. Int J Electrochem Sci. 2008;1:28.

5. Raja PB, Sethuraman MG. Mater Letters. 2008;113:6.

6. El-Etre A.Y. Corros Sci. 2003;2485:95.

7. Martinez S, Stern I. Applied Surface Science. 2002;83:9.

8. Mishra T, Khullar M, Bhatia A. Hindawi Publishing Corporation. 2011;11.

9. Guo S, Duan J, Tang Y, et al. J Pharm Biomed Anal. 2011;264:270.

10. Dahiru D, Sini JM. African J Biotech. 2006;941:5.

11. Shen X, Tang Y, Yang R, Yu L, et al. J Ethnopharm. 2009;555:60.

12. Plastina P, Bonofiglio D, Vizza D, et al. J Ethnopharm. 2012;325:32.

13. Jiang JG, Huang XJ, Chen J, et al. Nat Product Res. 2007;37:41.

14. Kubota H, Morii R, Kojima-Yuasa A, et al. Am J Chinese Medicine. 2009;597:608.

15. Kesavan D, Gopiraman M, Sulochana N. Chem Sci Rev Letters. 2012;1:8.

16. Al-Hashem A, Riad W. Mater Charact. 2002;37:41. 
17. Mansfeld F, Liu G, Xiao H, et al. Corros Sci. 1994;2063:95.

18. Manweld F, Lrtizet B. Electrochim Acta. 1992;2291:7.

19. Liu T, Yin Y, Chen S, et al. Electrochim Acta. 2007;3709:13.

20. Gharnit N, Ennabili A, El Hamdouni El-M. Dialnet. 2000;57:74.

21. Borgi W, Ghedira K, Chouchane N. Fitoterapia. 2007;16:9.

22. Mahboba BN, Rabia OA, Nabil AS, et al. Arab J Chem. 2010;79:84.

23. Latifa H, Mouna B, Arezki M. World Appl Sci J. 2013;1536:43.

24. Ghedira K. Phytotherapie-Springer Journal. 2013;149:53.

25. Benammar C, Baghdad C, Belarbi M, et al. J Nutrit Food Sci. 2014;8:13.

26. Borgi W, Chouchane N. J Ethnopharmac. 2009;571:3.

27. Abdeddaim M, Lombarkia O, BachaA, et al. Ann Food Sci Tech. 2014;75:81.

28. Pyun C, Park S. J Electrochem Soc.1986;2024:30.

29. Liu T, Yin Y, Chen S, et al. Electrochim Acta. 2007;3709:13.

30. Liu T, Chen S, Cheng S, et al. Electrochim Acta 2007;8003:7.

31. Robertson J. Corros Sci. 1991;443:65.

32. Millard SG, Law D, Bungey JH, et al. NDT \& E Int. 2001;409:17.

33. Hrussanova A, Mirkova L, Dobrev TS, et al. Hydrometallurgy. 2004;205:13.

34. Haschke JM, Allen TH, Stakebake JL. J Alloys Comp. 1996;23:35.

35. Popova A, Sokolova E, Raicheva S, et al. Corros Sci. 2003;33:58.

36. Zaid AA, Farooqui M, Janrao DM. J Chem, Biol Phys Sci. 2014; 2249.

37. Hammouti B, Zarrouk A, Al-Deyab SS, et al. Oriental J Chem. 2011;23:31.

38. Stupnišek-Lisac E, Gazivoda A, Madžarac M. Electrochim Acta. 2002;2:7.

39. Gašparaca R, Martin CR, Stupnišek-Lisaca E. J Electrochem Soc. 2000; 548:51.

40. Otmacic H, Stupnišek-Lisac E. Electrochim Acta. 2003;985:91.

41. Al-Luaibi SS, Azad S, Abdel-Amir H T. J Mater Environ Sci. 2011;148:55.

42. Zarrouk A, Hammouti B, Zarrok H, et al. Int J Electrochem Sci. 2011; 6261:74.

43. El-Sayed MS, Erasmusa RM, Cominsa JD. J Colloid Interf Sci. 2007; 470:7.

44. Hu L, Zhang S, Li W, et al. Corros Sci. 2010;2891:2896.

45. Abd El-Rehim SS, Magdy AMI, Khaled KF. J Appl Electrochem. 1999;593:9.

46. Ravichandran R, Rajendran N. Appl Surf Sci. 2005;449:58.

47. Khaled KF. Mater Chem Phys. 2008;104:11.

48. Larabi L, Benali O, Mekelleche SM, et al. Appl Surf Sci. 2006;1371:8.

49. Sherif ESM, Erasmusa RM, Cominsa JD. J Colloid Interf Sci. 2007; 144:51.

50. Liu BY, Liu Z, Han GC, Li YH. Thin Solid Films. 2011;7836:44.

51. Rosliza R, Wan Nik WB. Curr Appl Phys. 2010;221:9.

52. Amar H, Braisaz T, Villeminb D, et al. Mater Chem Phys. 2008;1:6.

53. Núñeza L, Reguerab E, Corvoc F, et al. Corros Sci. 2005;461:84. 